\title{
A dança dos Aruanãs: mito, rito e música entre os Javaé
}

\author{
SONia Regina Lourenço \\ Doutoranda do Programa de Pós-Graduação em Antropologia Social da UFSC \\ sonialouren@uol.com.br
}

\begin{abstract}
Resumo Este texto propõe uma análise do ritual - musical 'brincadeiras' (tykydisi) (Irasò) entre os Javaés, habitantes imemoriais do vale do rio Araguaia, em especial da região da Ilha do Bananal (TO). Os Aruanãs são seres mágicos do mundo subaquático (Berahaxti) trazidos pelo xamã para 'brincar' (cantar e dançar) com os seres sociais no mundo de fora (Ahana Òbira) durante um ciclo cerimonial. Em primeiro lugar, focalizo o ciclo cerimonial dos Aruanãs como a expressão máxima das prestações matrimoniais (tykòwy) entre sogros e genros; em segundo lugar, analiso as duplas de Aruanãs como formas corporais andróginas, em que o masculino e o feminino não prescrevem a diferença sexual porque os corpos dos Aruanãs são concebidos como corpos mágicos de um mundo sem afins e sem a diferença de gênero. As ‘brincadeiras' de Aruanãs são os rituais performativos em que a música e a dança propiciam a reatualização da mitocosmologia e a circulação das 'riquezas' entre os Javaés.
\end{abstract}

Palavras-chave: corpo; gênero; Javaé; música; ritual.

$\mathrm{M}$ INHA PESQUISA ETNOGRÁFICA foi realizada entre os Javaés que se autodenominam como Itya Mahãdu (o 'Povo do Meio'), e habitam a Ilha do Bananal chamada inỹ olona (o lugar de onde surgiram os inỹ) no vale do rio Araguaia. O território tradicional Javaé situa-se na região do interior da ilha, na parte leste dos rios Jaburu e Riozinho, rios que os separam do território Karajá, além da região dos afluentes da margem direita do rio Javaé. Os Javaés são um grupo de falante da língua Karajá, tronco Macro-Jê (Maia, 1986), com população de aproximadamente 1.400 pessoas, distribuídas em 12 aldeias (Rodrigues, 1993; 2008) $)^{1}$. A organização social dos Javaé apresenta a divisão entre metades cerimoniais, classes de idade, a endogamia de aldeia e de parentela, a uxorilocalidade, o casamento preferencial com primos cruzados bilaterais distantes, referindo-se aos afins com tecnonímios, desaprovando os casamentos interétnicos, embora atualmente registre-se um aumento destes (Rodrigues, 2008). As aldeias Javaé não seguem o padrão das aldeias radiais características dos grupos de língua Jê-Bororo (Carneiro da Cunha, 1993). As unidades uxorilocais (casas) são construídas ao longo de uma, duas ou três linhas retas e paralelas ao rio. Em oposição assimétrica ao lado do rio, situa-se a casa dos homens (ijoi heto) ou casa de Aruanã (Irasò heto) de acesso proibido às mulheres ${ }^{2}$.

1 As aldeias Javaé são Canoanã (Kanoanã), Boto Velho (Inãwèbohona), São João (1979), Wariwari (1993), Barreira Branca (1982), Cachoeirinha (1995), Imotxi (1998), Txukòdè (2001), Boa Esperança (2002), Barra do Rio Verde (2002), Taimỹ (2002), Wakòtyma (2005), (Rodrigues, 2008).

2 Ao longo do texto, uso as palavras com a letra $k$ entre vogais. Entre os Javaé e os Karajá há uma inflexão de gênero na fala masculina e feminina. As mulheres falam Hãkiriri e os homens Hairiri. 
A geografia do cosmos Javaé possui três planos: o mundo subaquático (Berahatxi- hetxi: nádegas, bero: do rio), inicialmente habitado pelos iñ , os humanos originais que subiram ao mundo de fora (Ahana Òbira, $\grave{o}$ : rosto/face, bira: lado, ahana: fora, o povo com a face de fora), e o mundo celeste (Biuwètyky - biu: chuva, céu, wè: barriga, tyky: corpo ou pele), habitado por seres também mágicos como alguns Aruanãs, os xamãs e Tanỹxiwè, o herói criador do mundo ${ }^{3}$. O conhecimento sobre os níveis cósmicos é um atributo dos xamãs, os únicos capazes de se comunicarem com os seres cosmológicos e orquestrar a vida cerimonial. O xamanismo é o locus do saber compartilhado na casa dos homens (ijoi heto) e capaz de permitir a realização dos rituais de iniciação masculina e do ciclo anual da dança dos Aruanãs. A categoria de Aruanã na linguagem nativa se chama Irasò (ra: cabeça; sò: vermelha, i: dele: 'a cabeça vermelha dele' (Rodrigues, 2008, p. 802, para a mesma tradução). São os xamãs que viajam até o mundo subaquático, onde vivem muitos Aruanãs, para 'verem' e 'ouvirem' sobre quais são brincadeiras e alimentos que os Aruanãs querem que sejam preparadas pelos pais (Irasò tyby) e mães (Irasò sè) de Aruanãs. Dançam e cantam, segundo o xamã, de modo semelhante ao que se realiza no mundo subaquático.

O ciclo cerimonial dos Aruanãs (Irasò) tem como prerrogativa central, a prestação matrimonial entre genros e sogros, na acepção nativa traduzido como o pagamento $(t y k o ̀ w y)$ pela vagina $(t y y)$ da esposa a seus afins e o acesso do marido aos prazeres da sexualidade. Pela regra uxorilocal, um homem ao receber a mulher de outro grupo (primo cruzado bilateral distante), entra numa relação de prestações matrimoniais, e passa a ter uma série de obrigações para com os sogros e cunhados. Assim, deverá pescar, caçar, cultivar a roça, arrumar a construção da casa, confeccionar cestos de palha, canoa, remo e pilão durante um bom tempo até que ele passe a ocupar a posição de sogro em relação a outro homem. Na narrativa mítica, Tanỹxiwè, o herói demiurgo, ao contrair o matrimônio com Myreikò, faz uma grande viagem para conquistar o sol e com ele iluminar o mundo para atender as exigências da sogra. Ele conquista o Sol, a Lua e as Estrelas do grande Iòlò Rararesà, o Urubu-rei ${ }^{4}$. Para os Javaé, o ciclo cerimonial dos Aruanãs existe por causa da prestação matrimonial entre afins e, ao mesmo tempo, põe em circulação a 'riqueza' (nohõ) de cada família na forma ritual da dança dos Aruanãs.

Os Aruanãs vêm a este mundo para experimentar e comer as comidas de suas mães rituais, as Irasò sè. As comidas põem em operação as brincadeiras rituais, ali- mentam a casa dos homens, mas também são as expressões do pagamento das prestações matrimoniais que os genros devem aos sogros. Durante todo ciclo ritual que pode durar de um a dois anos, os pais rituais de Aruanãs devem patrocinar todas as performances conduzidas pelo xamã. Uma prática que confere às famílias distinções sociais ao fornecer uma quantidade significativa de alimentos para a efetivação do rito.

Os Aruanãs são transferidos de geração a geração preferencialmente para o primogênito. Entre os Javaé há uma diferença entre o primogênito e o caçula. Idealmente, os primogênitos podem receber um Aruanã de seus parentes bilaterais, pois são eles que herdam de seus pais ou avós e passam a ser os donos de Aruanã (irasò wèdu) durante um novo ciclo. A permanência sob os cuidados de uma família se estende até o nascimento do primeiro filho, novamente o primogênito para quem será transmitido o Aruanã. Isso não significa que outros filhos que não sejam os primogênitos não possam receber os Aruanã. Na aldeia Wariwari, apenas um dos irasò wedu era o filho primogênito do casal.

As crianças ou adolescentes que são 'donas de Aruanã' (Irasò wèdu) mantêm uma relação de identidade cerimonial com os Aruanãs mediante a relação entre o tio materno e o sobrinho ou sobrinha. Tio materno e sobrinho (a) vivem uma relação cerimonial, alimentada pelos pais cerimoniais de Aruanã, o pai de Aruanã (irasò tyby) e a mãe de Aruanã (irasò sè). O tio materno chama o sobrinho de wara (wa: 'minha'; ra: 'cabeça'), e o sobrinho chama o tio de walana. A prestação matrimonial, expressa na dança dos Aruanãs, coloca o homem numa dupla posição, de devedor aos afins e recebedor das comidas rituais. Por um lado, um homem, ao casar, vai residir na casa da esposa de acordo com a regra da uxorilocalidade e da matrilinearidade. É ele quem tem a prerrogativa de alimentar o ciclo cerimonial como pai ritual de Aruanã (irasò tyby). Por outro, ele é o tio materno (o irmão da esposa) que retorna à casa natal para dançar como Aruanã na pista da mãe ritual (irasò sè), numa relação de identidade cerimonial com o sobrinho ou sobrinha (Rodrigues, 2008, p. 796). O tio materno em toda a vida cerimonial Javaé é aquele que leva o jovem iniciado (jyrè: ariranha) da casa da mãe para a casa dos homens onde passará a compartilhar dos segredos da vida ritual. Os xamãs também são os 'donos', pois são eles que trazem os Aruanãs do mundo subaquático. No início de cada ciclo ritual, o xamã vai até a casa da família que receberá os Aruanãs e entrega seu wanõhõ. A palavra wanõhõ significa 'meu cordão', o 'cordão do hàri'․ A chegada de novos

3 Uma análise mais profunda da cosmologia Javaé encontra-se em Rodrigues (2008).

4 Rararesà, o Urubu-rei representa a figura mítica do grande lòlò, posição de chefia política hereditária muito respeitada entre os Javaé.

5 Rodrigues (2008) traduz "nohõ" como 'bem precioso'.

6 Toral (1992, p. 261) traduziu nohõ como o "xerimbabo" da criança e "aquele que protege e propicía o crescimento" dela. 
Aruanãs cria uma atmosfera de alegria e expectativa na aldeia. Às mulheres são proibidas de 'olhar' para fora de suas casas em direção ao rio acima (ibòkò), no dia anunciado da chegada de Aruanãs. A elas, cabe a audição de toda a movimentação que ocorre na aldeia.

Por que chamo as brincadeiras de Aruanãs como ritual-musical? Porque elas são definidas, pelos Javaé, como os eventos performativos mais relevantes de sua vida social, além, é claro, do ritual de iniciação masculina (Hetohokỹ: ritual da casa grande). De acordo com Tambiah $(1985$, p. 128) os rituais se definem pelo seu poder de comunicação, pela constituição em seqüências padronizadas de palavras e atos (expressos em múltiplos meios - diálogos cerimoniais, musicais, pinturas corporais e danças), pela formalidade e esteriotipia, pela condensação e repetição e pela produção e reatualização de valores sociais durante a performance. Brincar (narakyna) na acepção Javaé, não é uma noção que conota apenas divertimento tal como os jogos realizados logo após cada 'brincadeira', mas a expressão máxima do ciclo cerimonial que envolve as prestações matrimoniais entre afins.

Os ritos de Aruanãs são chamados de 'brincadeiras' (tykydisi - tyky: corpo/pele; disi: brincadeira), na tradução significa 'brincadeiras do corpo/pele', divididas entre grandes e pequenas: as 'brincadeiras' pequenas são chamadas de narakyna sõmõ sõmõ (sõmõ: pequeno), e as brincadeiras grandes de tara(k)ynahaky (ta: sua ra: cabeça ky: carne ou algo dentro da cabeça), momento em que os Irasò dançam com suas irmãs rituais (Irasò Didi). Rodrigues (2008, p. 849) encontrou a palavra narakyna hakÿ para traduzir o sentido de 'brincadeiras grandes'. Na performance, as jovens (ijadoma) dançarinas (adusidu) entregam a comida ritual (idò) para os Aruanãs.

As brincadeiras rituais etnografadas por mim abrangem uma parte do ciclo anual que pode durar de 1 a 2 anos. Idealmente, cada dupla deve ficar na aldeia durante um ciclo inteiro ou dois ciclos, fazendo várias brincadeiras de forma seqüencial, embora exista uma variação na seqüência, incluindo algumas que se repetem entre duas delas. Assim, as brincadeiras de 'despedida' e de 'chegada' são realizadas do mesmo modo e numa seqüência ordenada. $\mathrm{O}$ ciclo cerimonial que registrei foram as brincadeiras 'grandes' com duração de 4 a 5 dias: Hanỹkỹ (óleo de tartaruga); Kobi(k)u (peixe assado); Iwodudu (pastel de peixe); Bidi (mel); e Beto/Kuladubiditò (calogi/mel de criança); as brincadeiras 'pequenas' com duração de 2 a 3 dias: Orinỹkỹ (carvão); Axi(k)òròrò (cipó); Wyhyraheto (arco e flecha); Ixỹy (ruas da aldeia/espaço feminino); Halokulorè (buraco); e a brincadeira de 'despedida de Aruanã' Imonahakỹ (grande calogi). Todas elas são seguidas pelos jogos entre as classes de idade de rapazes (weryrybò) e moças (ijadoma), interação de potenciais cônjuges (Rodrigues, 2008, p. 850852). Cada brincadeira tem um 'dono' (wedu), uma família responsável pela caça, pesca e preparação das comidas rituais que conferem o nome às brincadeiras, especialmente as 'brincadeiras grandes' guarnecidas com comidas de origem animal, peixe ou caça (irasò dò: comida dele). As brincadeiras pequenas são alimentadas por comidas de origem das roças, mandioca e milho (irasò rasüna) e iweru, calogi feito de arroz, uma bebida não fermentada.

Quando cheguei à aldeia Wariwari, nas duas últimas semanas de março de 2007, os Javaé se preparavam para o início da brincadeira Hanykỹ (óleo de tartaruga). Esta é classificada como uma das "grandes brincadeiras" (tara(k)nahakỹ ou narakyna hakỹ) com duração de 3 a 4 dias, marcada por uma noite inteira de performance de música e dança. $\mathrm{O}$ registro das canções só começou no dia 01 de abril, pois ainda conversava com as famílias, donas de Aruanãs e o xamã, sobre a pesquisa cujo foco era o ciclo cerimonial dos Aruanãs, especialmente as músicas.

Durante o início das performances, os Aruanãs cantam e dançam as músicas de saída dele (Iòlòna wii), e na finalização as músicas de entrada dele (Iròtena wii $)^{7}$. Cada dupla de Aruanãs possui as suas músicas de entrada e de saída que podem se repetir ao longo de uma seqüência de 'brincadeiras'. A performance de música e dança dos Aruanãs e das Irasò Didi (irmãs rituais) realizam-se no Irasò Ube (caminhos ou estradas dos Aruanãs; ube significa a palma ou linhas dos pés: waa ou mãos: debò). As estradas de Aruanãs ligam o espaço dos homens (ijoina) situado na frente da casa dos homens ao espaço das mulheres (hirarina) na parte da frente das unidades uxorilocais. Cada Aruanã dança na estrada de seu pai (irasò tyby) ou mãe (irasò sè) que devem fornecer comida ritual antes, durante e depois de cada performance.

As estradas de Aruanãs possuem uma divisão ternária, associada aos três mastros do Hetohokỹ (dentro da casa grande) e às três portas da casa de Aruanã das metades cerimoniais: Ibòkò (porta no sentido rio acima) é Saura (associada ao macaco-prego e à pena de arara-azul); Tya (porta do meio) é Saurahakỹ (associada a alguns Worosĩ que entram apenas no ritual do Hetohoky $\tilde{y}^{8}$ ); e Iraru (porta no sentido rio abaixo) é Hiretu (associada ao gavião-carcará e à pena de araravermelha). A continuidade das metades cerimoniais Saura e Hiretu é matrilinear. É no mito que se encontra a distinção entre as metades: Saura é associada aos irmãos Ijana(k)atu e Hiretu associada aos irmãos

7 A partícula / sempre se refere a algo 'dele', do Aruanã.

80 Hetohokỹ (o ritual da casa grande) é o ritual de iniciação dos meninos ou adolescente, tradicionalmente realizado na estação das chuvas, entre dezembro e janeiro. 
Nabio que perderam a luta para os Ijana(k)atu9. Durante a luta, os Ijana(k)atu mataram os irmãos Nabio, e 'por isso', conta a narradora, no lugar da casa dos Nabio ficou um gavião que chorava (cantava) todo dia de manhã e a tarde porque não tinha comida. Tolòrà ouviu o choro e foi na direção do som. Foi esse evento sonoro que desencadeou a subida de Tòtòra ao mundo de fora, para apaziguar os conflitos, pois é dele esta atribuição, a chefia hereditária dos Iòlo, posição prestigiada entre os Javaé. O desenho da aldeia Javaé é homólogo a aldeia cosmológica na qual a casa dos homens localiza-se no meio (tya) das duas extremidades rio acima e rio abaixo.

A categoria nativa para música é wii (tudo o que é 'bom' e 'belo'), wiidu é o compositor, aquela pessoa que 'sabe fazer e cantar bem as músicas', sendo a palavra kumawii (voz boa) traduzida como o cantor de grande qualidade na voz. O cantor e compositor, já um mestre de música, também é identificado com boa audição/ouvido (nohõtiwii - wii: bom, nohõti: ouvido), com 'boa audição/ouvido para aprender música', ou com boa memória (rakywii - ra: cabeça, ky: memória, algo de dentro da cabeça, wii: boa), ou ainda como 'gente que aprende rápido' (iñ̃ nohõtitere). O verbo 'ouvir' parece indicar para uma posição especial da percepção auditiva como correlata de 'aprendizado, memória, criação' em relação à percepção visual específica das qualidades sensoriais dos xamãs, semelhante aos Kamayurá e Suyá para os quais ouvir sugere um "índice de virtuosidade nas artes da música e da arte verbal" (Menezes Bastos, [1976]1999, p. 102; 2006, p. 570; Seeger, 1980, [1987] 2004).

Noto que as noções da semântica corporal masculina são as mesmas usadas na definição formal das músicas, conceituadas como o 'corpo' e o 'pênis' da música. Todas as canções de Aruanã (Irasò wii) são divididas em três partes que se repetem ao longo da execução: a primeira é Iumỹ ('corpo dele'); a segunda é 'pênis dele' (Tõo) $)$ literalmente 'o pênis e o corpo da música'; e a 'cabeça do pênis da música de Aruanã' (nõra ou irasòwii ranõra - ra: cabeça; nõ: do pênis), que indica apenas a extremidade final da letra e da linha melódica de uma canção. Tudo indica que essa divisão inclui tanto uma diferença nas letras das canções quanto em termos musicológicos, linha melódica, tonalidade e ritmo. A música entre os Javaé é vocosonora e acompanhada do chocalho (weru) globular, feito de cabaça de cuité e do chocalho feito de casco de veado (bororè) amarrado nos tornozelos dos Worosỹ, que cantam no ritual do Hetohoky. Tanto o chocalho de cuité quanto o de casco de veado, dão o ritmo às canções ${ }^{10}$.

A performance musical dos Aruanãs se faz com dança, ou seja, ela é coreológica no sentido em que as canções só são cantadas quando os Aruanãs/Irasò estão dançando. A palavra nativa para dança é ixe ou bèsèkè (dançar, descer, cair). De modo semelhante aos Mehinaku (Véras, 2000, p. 73), entre os Javaé a dança se caracteriza mais pelo movimento catabático em direção a terra e ao chão, e menos acrobática em direção ao alto. O mundo sonoro Javaé possui uma série de categorias de músicas cantadas pelos Aruanãs de acordo com a noção de temporalidade do dia e da noite: as músicas noturnas (bèdèsò wii entre 20 e 23 horas), as músicas da madrugada (bi(k)urana wii entre 3 e 6 horas), as músicas matutinas divididas em dois horários (rudi wii entre 6 e 7 horas, e iwisitòbòrèhè e iwisirèhè entre 9 e 10 horas), as músicas entre o fim da manhã e a tarde (iwiidohotinà entre 11 e 17 horas), e as músicas vespertinas (txiorò wii entre 16 e 18 horas ${ }^{11}$. Há ainda as músicas cantadas pelos xamãs durante um ritual xamânico de cura. Na perspectiva de Menezes Bastos (1990; 1999; 2007), música e tempo estão inscritos numa estrutura seqüencial, ou seja, a forma como os gêneros musicais são socialmente organizados. O sistema intercancional do rito se estrutura de acordo com um modo de concepção do tempo, ou seja, as músicas operam como se fossem dispositivos organizadores da temporalidade, isto é, todas as músicas são classificadas de acordo com as horas do dia ou da noite, como fazem os Kamayurá (1990).

De acordo com a classificação nativa, as músicas de Aruanãs variam de acordo com cada dupla de Aruanãs. A variação e a diferença entre eles e entre um conjunto de músicas cantadas em outras modalidades rituais (Hetohokỹ, Marakasi e Iweruhukỹ) sugerem que as músicas de Aruanãs se constituem como um gênero musical no sentido bakhtiniano de gêneros de discurso estruturados com base em conteúdo temático, do estilo e da construção composicional (Bakhtin, 2000, p. 279) ${ }^{12}$. As músicas de Aruanãs são, a meu ver, subdivididas em

9 Em outra parte da narrativa, os irmãos ljana(k)atu se casam com as filhas do sol (Tхиu), e conquistam o prazer sexual. Este mito trata da "vagina dentada": os irmãos ao introduzirem na vagina das mulheres, axi (timbó) matam as piranhas que havia em seu interior, restando uma só responsável pelo ciclo menstrual.

10 Paul Ehrenreich que estudou os Karajá em 1888 (1948, p. 55), fala da existência de uma trombeta (adjurane), uma grande cabaça aberta nas duas extremidades e que em uma delas se coloca um tubo de taquara com fenda lateral. Menciona ainda a existência de flautas de pan também feitas de taquara. Na minha pesquisa de campo, perguntei a vários Javaé sobre a existência de algum instrumento de sopro entre eles ou entre os Karajá, mas a resposta sempre foi negativa.

11 Ver Rodrigues (1993) para uma primeira abordagem das categorias de música Javaé.

12 No campo dos estudos de antropologia da música, o conceito de gêneros de discurso de Bakhtin (200o) aplicado no campo da música como gêneros musicais tem sido rentável na análise das classificações que os interlocutores fazem de seu universo musical. Ver Piedade (2004, p. 07), Mello (2005) e Montardo (2002). 
subgêneros, pois cada performance de Aruanã apresenta um repertório de canções, um estilo de cantar e dançar específicas de cada um, ora compostas pelos mestres de música e entregues a eles, ora trazidas de Berahatxi ou Biuwètyky pelos xamãs. Os subgêneros musicais podem ser divididos de acordo com cada dupla de Aruanã.

A pesquisa de campo realizada em três aldeias Javaé (Wariwari, Boa Esperança e Canoanã) possibilitou identificar 6 subgêneros musicais: músicas de Hãkiriri; músicas de Ijareheni; músicas de Weru, Aruanã que recebe o nome do chocalho globular para diferenciá-lo de outro chamado Debò que canta sem o instrumento; músicas de Iraburé; músicas de Iobèsè; e músicas de Xiburè, Aruanã de Biuwètyky (mundo celeste) que canta com chocalho branco. A quantidade de duplas de Aruanãs em cada aldeia pode variar de acordo com o tamanho e o número de habitantes de cada uma. Em Wariwari, encontrei 3 duplas de Aruanãs - Ijareheni, Hãkiriri e Weru, além de Làteni que não é Aruanã -, em Boa Esperança, uma dupla de Iraburè, e em Canoanã 5 duplas - Ijareheni, Hãkiriri, Weru, Iobèsè e Xiburè. De acordo com os Javaé, em 2007, a aldeia São João contava com a presença de 12 duplas de Aruanãs. As brincadeiras apenas são realizadas em aldeias que tenham casa dos homens e/ou casa de Aruanã e xamã ${ }^{13}$. O chocalho globular chamado weru é ornamentado com plumária de pássaros e possui orifícios para a saída do som. Os Aruanãs Ijareheni, Weru, Hãkiriri e Xiburè cantam e dançam com o weru, ao passo que os Aruanãs Debò, Iraburè, Ija(k)uhi e Iobèsè, não. Os compositores (wiidu) são os donos das músicas, mas não são eles que necessariamente as cantam. Há casos raros de mulheres que compõem músicas e as entregam para seus maridos ou irmãos levarem à casa dos homens (Rodrigues, 1993). Brígido (1994/1995, p. 306) mostra que nas aldeias Karajá, há mulheres compositoras que podem sonhar com alguma canção e narrar: "para o marido ou para o pai. Ele passa então a cantar muitas vezes para gravar, mas ninguém pode saber que aquele canto veio de mulher" 14 .

As mulheres como excelentes ouvintes, e na condição de dançarinas (adusidu) na época de sua juventude, conhecem bem o repertório das músicas. Uma das principais dançarinas da aldeia Wariwari trabalhou comigo na tradução de algumas letras de música. Segundo ela, ao dançar com os Aruanãs, elas aprendem a cantar, memorizando as letras das canções. Os meus dados indicam que há os mestres de música (os compositores) e os cantores que aprendem na casa dos homens repertórios de um ou outro Aruanã. Por diversas vezes, observei o principal compositor e cantor da aldeia transmitindo música para os Aruanãs ou cantando no espaço masculino (ijoina) para ensinar os rapazes iniciados (weryrybò). Tudo indica que a lógica de transmissão entre as gerações existe ao lado dos saberes compartilhados da casa dos homens de modo similar a transmissão dos Aruanãs. No entanto, se os Aruanãs são, por excelência, o 'bem precioso' (nohõ) Javaé (Rodrigues, 2008, p. 559 e comunicação pessoal, 06/05/2008), não significa que as músicas tenham o mesmo significado, ou seja, elas não são consideradas como nohõ, segundo um homem Javaé e filho de um grande compositor reconhecido já falecido ${ }^{15}$.

Dos cantores procura-se ocultar a identidade, mesmo que se saiba quem são os grandes cantores de cada aldeia. Dependendo da dupla de cantores, as mesmas canções cantadas por diferentes duetos alcançam timbres diferentes. O início de cada canção é executado na frente da casa de Aruanã, também chamado de ijoi, a praça do grupo de homens. Inicialmente, cantam a abertura das duas estrofes da canção, Iumỹ e Tõo, acompanhados do chocalho weru que dá a pulsação rítmica bem marcada da canção, para, em seguida começar a dança pela estrada de Aruanã (Irasò ube), a finalização (ranõra) é executada de frente para o espaço feminino, depois retornam para o ijoina em silêncio. Ehrenreich (1948, p. 76) observou que entre os Karajá, a transmissão das canções é hereditária, "de pai para filho, e dizem ser compostas em linguagem arcaica e incompreensível ao comum da população". Lima Filho (1991, p. 87) mostra que os cantores gostam tanto de cantar as mais antigas como de criar novas canções, que "correm pelas diversas aldeias associadas com os nomes de quem as fez". Tanto entre os Karajá quanto entre os Javaé, a circulação das canções através das gerações é notável. Os compositores de cujas canções são consideradas 'mais bonitas' e 'difíceis' de cantar são identificados por outros compositores, e são reconhecidos por terem 'boa memória'.

As canções circulam por diferentes gerações e são cantadas por diferentes cantores durante os ciclos cerimoniais, ou seja, a música composta por um mestre de música de uma determinada aldeia pode

13 Há outros gêneros musicais entre os Javaé como as músicas de Worosỹ, cantadas exclusivamente no ritual de iniciação masculina, - Hetohokỹ, seguindo uma ordem temporal de sua execução por três Worosỹ diferentes; as músicas de lweruhukỹ, ritual realizada décadas atrás na estação da seca e Marakasi, músicas e danças aprendidas com os Karajá e executadas na estação seca logo depois da brincadeira lwodudu.

14 Na minha pesquisa de campo não encontrei nenhuma canção em que a autoria fosse atribuída a uma mulher, talvez por que os homens ocultam qualquer participação de mulheres na vida cerimonial. Isso não significa que a composição das músicas de Aruanãs seja um ato criativo exclusivamente "masculino".

15 Brígido (1994/1995) observa que entre os Karajá, há músicas que são sonhadas por homens ou por mulheres enviadas por "espíritos". Não possuo qualquer registro da existência de músicas recebidas em sonhos por "espíritos" entre os Javaé. 
ser cantada por outros cantores de aldeias diferentes e respeitando a mesma estrutura composicional. Todos os homens, jovens e mais velhos, falaram de usos de recursos para a composição musical dentro da divisão Iumỹ e Tõõ, como abreviações de palavras inteiras para se ajustar na música, ou recursos sintáticos para ocultar a identidade de pessoas de quem ou para quem se canta. Na substituição de várias palavras por combinações de fonemas - como he hÿ, he he - os performers têm grande liberdade de se expressar musicalmente, pois eles não estão longe das regras que governam o acompanhamento das palavras, ou das restrições rítmicas de que cada sílaba de uma palavra deve ser acompanhada por somente um tom. Noto uma semelhança entre os Javaé e os Kamayurá no que se refere à diferença entre letra e música. Segundo Menezes Bastos (1999) para os Kamayurá a letra 'vai dentro da música'.

No caso da música de Aruanã, registrei algumas com a identificação do compositor, outras feitas como acusações, encomendadas para falar de 'alguém' publicamente, outras como se fossem comentários depreciativos em forma de música de homens de povos diferentes (Karajá e Xambioá). O cuidado em ocultar a identidade de quem se fala nas canções ou para quem se canta pode estar relacionado com a questão da negação da afinidade. Segundo Rodrigues (2008), a evitação dos nomes está relacionada com a negação da afinidade, e esta é uma das razões pelas quais os Javaé fazem uso dos tecnonímios, referindo-se a alguém como o 'pai de' ou 'mãe de alguém', pois chamar alguém pelo nome equivale a um xingamento. No caso dos próprios parentes, chama-se pelos termos de parentesco como por exemplo, tio (walana), avô (labié), avó (lahi), mãe (nadi), e pai (waha). Para Rodrigues,

vocalizar os nomes de alguém se associa com a abertura dos corpos daquele com quem se fala, pois a afinidade é pensada como o estado poluído de abertura dos corpos, em oposição ao parentesco, o estado purificado de fechamento dos corpos.

Nas aldeias Karajá, Brígido (1994/1995, p. 306) observa que algumas canções são criadas em parceira e cantadas para a memorização, muitas vezes com a finalidade de acusação de uma determinada pessoa, sem que o nome de alguém jamais seja revelado "dizem que pronunciar o nome da pessoa neste local é perigoso", embora a pessoa saiba que a canção é dirigida para ela, e esta pode procurar um bom compositor e encomendar uma canção como resposta às críticas de outrem.

Em algumas letras de canções, executadas no momento especial de entrega do idò (comida ritual), pelas mãos das adusidu (dançarinas e irmãs rituais), aos Aruanãs, não há qualquer comentário sobre a relação entre alteridade e feminilidade. Estas canções de Ijareheni, Hãkiriri e Weru foram cantadas na Brincadeira Hanỹkỹ (óleo de tartaruga), com início dia 31 de março e término 4 dias depois, tendo seu ápice na manhã do dia 03 de abril de 2007, após uma longa noite de canções na aldeia Wariwari.

Qual a seqüência da brincadeira? Os Aruanãs saem da casa dos homens, tocando o chocalho até a extremidade feminina da estrada para receber das mãos das Irasò Didi, a comida ritual (idò). Atrás dos Aruanãs, as metades cerimoniais (Saura e Hiretu) acompanham emitindo os vocalizes $\mathrm{He} H e \mathrm{He}$ nos três momentos que os Aruanãs cantam as partes formais da música (Iumỹ, Tõõ e ranõra). Na extremidade da estrada (Irasò Ube), e no espaço feminino (hirarina), as Irasò Didi vão ao encontro dos Aruanãs, entregam o recipiente com a comida. Nesse momento, os Aruanãs voltam apenas cantando sem tocar o weru para a outra extremidade de frente para a casa dos homens (ijoi heto) e entregam para as dançarinas o recipiente da comida ritual. Pela segunda vez, os Aruanãs cantam e dançam com o weru, ao passo que as adusidu dançam de frente para eles, equilibrando-se cuidadosamente para não derrubar o recipiente, pois seria um erro imperdoável. Novamente, na extremidade feminina, as adusidu entregam aos Aruanãs a comida ritual e seguem dançando até a casa dos homens, lá, um grupo de rapazes iniciados (weryrybò, bodu) recebem das mãos dos Aruanãs a comida ritual que é levada para dentro da casa dos homens. Pela terceira vez, os Aruanãs dançam no Irasò Ube, tocando o weru e rumo à finalização da dança. Depois, voltam para a casa dos homens, e lá, a comida ritual será partilhada com os rostos de homens e Aruanãs de frente para o leste, em direção ao sol nascente. A performance não termina aí, ela continua por mais uns 40 minutos com canções e danças dos Aruanãs que encerram a brincadeira ritual cantando as músicas de entrada na casa de Aruanã. Momentos depois, segue o jogo entre os jovens rapazes (weryrybò) e moças (ijadoma), contexto sem a marca da rigidez e do formalismo da dança dos Aruanãs. Agora, os corpos brincam numa atmosfera lúdica. Pétesch (2000, p. 107) chama, apropriadamente, estes jogos de 'ritos de inversão', pois provocam uma ruptura na ordem cerimonial, constituindo-se de aspectos 'dessacralizante' e 'catártico'.

Observo que grande parte do repertório musical dos Aruanãs Javaé tem como temática principal as relações sexuais entre homens e mulheres, ou as mulheres como um sujeito com desejos sexuais incontroláveis. Outros temas são cantados e, portanto, outros sentidos e significados são expressos musicalmente. Embora, para muitos Javaé, homens especialmente, os temas das canções "só tratam de bobagens"; "só cantam sobre mulher"; ou ainda "só falam de sacanagem”. Rodrigues (1993, p. 293-315) analisou 18 letras 
de canções de Aruanãs (Weru, Debò, Ijareheni e Hãkiriri) da aldeia Canoanã e constatou que o tema principal das canções são as mulheres, ora como esposas, ora como parceiras sexuais.

Três pesquisadores estiveram na aldeia Hãwalò (Santa Isabel do Morro) interessados na música Karajá. O primeiro deles foi Desidério Aytai (1979, p. 263-264), que analisou 23 cantos e concluiu sua investigação oferecendo uma análise estatística dos 23 cantos que transcreveu e mostrou que a escala preferida dos Karajá é a "escala tetratônica", e que a escala pentatônica é a mais freqüente. Suely Brígido (1994/1995), na sua coleta e transcrição musical de 150 canções de Aruanãs (Weru, Ijareheni e Txaòhi), inclui as aldeias Boiry (Fontoura) e Krehãwa (São Domingos). Como tema principal a associação das mulheres com a sexualidade, a traição e amantes insatisfeitas. E, por último, Conrad (1997, p. 54) que gravou uma canção do Aruanã Weru numa brincadeira ritual, e outras canções na cidade de Formoso do Araguaia. São oito canções do mesmo Aruanã. Conrad observou variações na linha melódica entre os dois cantores. A temática das letras destas canções trata do desejo sexual de uma mulher não-índia (tori) que, insatisfeita, busca o prazer sexual se masturbando; a mulher que fala com a filha sobre o homem desejado; a mulher que mente sobre um namoro com um homem. Nesse repertório Karajá, as mulheres são descritas como seres insatisfeitos sexualmente, e os homens são colocados na posição daqueles que sofrem deste desejo sexual incontrolado das mulheres. Esta oposição da identidade de gênero nas canções é uma reflexão sobre a alteridade que é, para os Javaé, feminilidade. Lima Filho (1994, p. 109) anota que "as músicas de Aruanãs têm um teor pejorativo e geralmente narram algum acontecimento em que as mulheres são insultadas".

As canções de Aruanãs que gravei com um grande compositor e cantor da aldeia Wariwari têm como tema central, as mulheres. De acordo com a explicação deste mestre de música, estas canções foram há muito tempo cantadas em outras aldeias por ele e outros cantores. Entretanto, quando comecei o trabalho de tradução das letras de canções cantadas nas brincadeiras rituais, percebi que as letras tratavam de um conteúdo temático muito variado. São eventos de caça, de pesca, de desejo sexual, de mulheres sem controle sobre seus corpos, de traição, de xamanismo, de seres míticos, de brigas, de sarcasmo sobre os nãoíndios, de canções na língua do povo Wou (Tapirapé) sem tradução, e de canções de Berahatxi intraduzíveis. Os homens Javaé reconhecem que as músicas que já "vêm prontas de Berahatxi" são de difícil tradução, assim como aquelas cantadas por Hãkiriri, Aruanã que canta muitas canções do povo Wou (Tapirapé), com quem os Javaé tiveram contato e muitos empréstimos culturais.

\section{As máscaras de Aruanãs e o discurso do segredo}

Na literatura sobre os Karajá e Javaé, alguns pesquisadores afirmam que as máscaras de Aruanã representam peixes (Ehrenreich, 1948, p. 72; Conrad, 1997; Lima Filho, 1994), mas os Javaé não confirmam essa definição. Embora, os Aruanãs tenham alguns nomes de peixes ou pássaros, como Bisani Weru, em que Bisani é um passarinho (não identificado). Para os Javaé são apenas nomes e não representam nenhuma espécie aquática ou terrestre.

Como já disse, os Aruanãs são considerados seres mágicos do mundo celeste ou do mundo subaquático. Chegam sempre em duplas, e, em duplas cantam e dançam no palco cerimonial da aldeia, uma performance de duetos. No corpo dos Aruanãs, não há nenhuma forma visível da diferença de gênero. A explicação do xamã e de alguns homens Javaé é que 'um é feminino e o outro é masculino', o que não significa dizer que um seja homem (habu) e outro seja mulher (hawyky), ou seja, não há, na teoria nativa, uma equivalência entre estes termos. Ityky ou tykytyby são conceitos Javaé para as máscaras e para os corpos dos Aruanãs. A idéia de 'roupa', 'pele' ou 'corpo' evoca a noção de 'roupa' na discussão do perspectivismo ameríndio (Viveiros de Castro, 1996, p. 133). Nessa abordagem, a "roupa esconde uma forma interna humana, normalmente visível apenas aos olhos da própria espécie ou de certos seres transespecíficos, como os xamãs".

No caso dos Aruanãs, a 'roupa' (tyky) ou máscara não indica uma subjetividade ou um espírito do animal, ao contrário, são 'corpos mágicos' conceitualizados como sendo um masculino e outro feminino, diferente, portanto, de uma 'essência' antropomorfa de tipo espiritual de uma aparência corporal (Viveiros de Castro, 1996, p. 117). Para os Javaé, o ponto de vista é o corpo, pois os Aruanãs têm um corpo diferente, a 'pele velha' (tykytyby), a mesma do mundo cósmico, definido como um mundo sem morte, sem doenças, sem afins e sem a diferença de gênero. São outras afecções. Diferentemente, para os Wauja do alto Xingu, as máscaras são 'roupas' (naí), como “uma exterioridade animal ou monstro que recobre uma interioridade antropomorfa ou zooantropomorfa, conhecida como yerupoho" (Barcelos Netto, 2002, p. 126). Entre os Javaé, ao vestir uma 'roupa-máscara', os dançarinos não estão ocultando uma essência humana sob a aparência animal, mas ocultando um corpo humano sob a aparência de outro corpo, ativando o potencial do que seria o corpo de Aruanã. A permutabilidade dos corpos funda-se na equivalência entre corpos: corpos dos seres sociais inexoravelmente abertos e os corpos mágicos dos Aruanãs eternamente fechados. Os corpos dos Aruanãs, têm um ponto de vista de um mundo marcado pela imortalidade, pela temporalidade mítica e pela permanência, 
e sua 'aparição' não deve ser confundida com a noção de representação porque, para os Javaé, não são os homens que cantam e dançam, mas os próprios Aruanãs de quem os homens usam as 'peles velhas aqui no Anaha Òbira'.

Há um processo de reversibilidade de pontos de vista. Explico melhor: os Aruanãs cantam sob o ponto de vista dos homens, porém, eles não são 'homens', mas seres sem gênero, assexuados. Seria então uma dialogia no sentido bakhtiniano entre esses sujeitos, um falando por meio do outro, como no caso da música entre os Araweté quando o xamã canta algo dito pelos Mâ̂, citado pelo morto, referente a ele (xamã) (Viveiros de Castro, 1986, p. 586). No contexto Wau$\mathrm{ja}$, as flautas são a presentificação dos apapaatai (Piedade, 2004, p. 226). De modo similar, a máscara de Aruanã é a presentificação dos seres subaquáticos ou celestes. De outra perspectiva, é como se o masculino e o feminino associados aos Aruanãs tivesse dentro de si uma forma que só se torna visível como 'androginia transformada' (Strathern, 1988).

Rodrigues sugere que as duplas de Aruanãs podem ser pensadas como seres 'andróginos' (2008, p. 294), justamente pela explicação nativa de que não se trata de seres com uma identidade de gênero definida, mas pela categorização das partes das duplas serem: uma feminina e outra masculina. A existência de uma pena azul e outra vermelha no alto da máscara de cada um dos integrantes da dupla permite a única identificação, sendo da pena azul, como a parte masculina, e da pena vermelha como a parte feminina. As máscaras cobrem a cabeça, o tronco e as coxas dos dançarinos. Somente os pés e os braços ficam descobertos, justamente para dar mobilidade ao dançarino. Assim, compartilho com Rodrigues o fato de que os Aruanãs podem ser pensados como formas corporais andróginas, entre o masculino e o feminino. Os corpos dos Aruanãs performatizam, de modo semelhante ao do contexto melanesiano, um gênero estético andrógino. Há uma mudança nos corpos dos homens (dançarinos mascarados) marcados anteriormente pela diferença de gênero que no âmbito do ritual passam a englobar o feminino na sua constituição. Entretanto, isso não resume tudo, há outras implicações que não serão discutidas aqui.

O que faz os adolescentes, meninos ou meninas, crescerem são substâncias mediadas pelos seus pais (caça e peixe) e produtos da roça (mandioca, milho), e preparados pelas mães na forma de comida ritual para alimentar os Aruanãs e o grupo cerimonial (ijoi heto), assim como grande parte da aldeia que partilha destes alimentos. Para os Javaé, os Aruanãs fazem os adolescentes crescerem 'fortes e rapidamente'. Tudo parece como se a parte masculina e feminina das duplas de Aruãnas, fossem partes constitutivas do crescimento dos adolescentes, ainda não definidos de acordo com uma identidade de gênero homem (habu) e mulher (haw $k$ ky), apenas como seres sociais incluídos em determinadas classes de idade masculinas (weryry: menino e weryrybò: rapaz) e femininas (hirari: menina e ijadoma:moça), idealmente de corpos fechados, porque ainda não se casaram e não tiveram filhos, signo da abertura corporal e da inscrição da diferença de gênero. De acordo com Rodrigues (2008), existe uma relação entre corpos mágicos (fechados, estáticos e menos transformados, associados ao mundo masculino) e os corpos sociais (abertos e de fluxo constante e mais transformados, do mundo feminino). Antes da ascensão dos inỹ originais do mundo subaquático (Berahatxi) para o mundo de fora (Ahana Òbira), os corpos mágicos não conheciam a diferença sexual e de gênero, a aliança matrimonial, a procriação física, o desejo sexual e a morte. A abertura e a transformação social dos corpos é um evento ocorrido com base em aliança matrimonial.

A título de hipótese, os rituais de Aruanãs para além de sua armadura sociológica - a prestação cerimonial - parecem operar uma reatualização da mitocosmologia. As narrativas míticas apresentam tanto uma 'sutileza estética' quanto uma 'sensibilidade moral', uma vez que as relações entre afins, o mundo da morte, da aliança, da sexualidade, de um mundo com gênero e da transformação se opõem ao mundo da imortalidade, da ausência de aliança e da sexualidade, sem a inscrição da diferença de gênero. Se o ciclo anual dos Aruanãs pode ser entendido como uma teatralização de um estado mágico, sem alteridade ou diferença de gênero, então, tudo se passa como se a performance dos Aruanãs e das dançarinas fosse um momento em que a diferença de gênero não existisse. E cada ciclo como se fosse uma constante recriação da imortalidade desejada.

A casa de Aruanã, espaço de repouso das máscaras, é terminantemente proibida às mulheres. Há o discurso do segredo do que ocorre no interior da cada dos homens (ijoi heto) e o que mais envolve as máscaras. Assim, tudo que envolve o segredo em torno dos Aruanãs não deixa de produzir uma condição instável, constantemente ameaçadora pela possível acessibilidade das mulheres à casa dos homens, também chamada casa de Aruanã (Irasò heto). As mulheres sabem que não são os Aruanãs de verdade que dançam ali, mas seus maridos, cunhados ou irmãos que cantam e dançam. No entanto, elas compactuam do discurso social de que não sabem do segredo e de que as máscaras, chocalhos e todos os objetos da vida cerimonial masculina Javaé são, metaforicamente, índices da tentativa masculina de recriação dos mundos cosmológicos (Berahatxi e Biuwètyky) tão desejados após a morte. Gregor e Tuzin (2001, p. 317) argumentam que virtualmente o segredo é 'vazio' de conteúdo, pois apenas oculta detalhes da confecção dos rituais masculinos. Tanto na Amazônia quanto na Melanésia, manter os olhos de mulheres e meninos não iniciados excluídos, mesmo que de forma dramática, é produzir a diferenciação 
social, sem cristalizar fronteiras rígidas entre homens e mulheres, o feminino e o masculino.

Assim, na Amazônia e na Melanésia, os objetos de cultos que incluem flautas e trompetes, produzem sons que podem ser ouvidos, mas não vistos. Tudo parece como se o ato de ver fosse a significação de uma ação de apropriação e diferentemente da audição. Olhar é perigoso. Entre os Javaé, assim como entre os Sambia e os Yahgan, os noviços são constrangidos a não revelar o segredo às mulheres, podendo sofrer algum tipo de sanção. Se há barreiras físicas na casa dos homens, como paredes que servem para preservar o segredo, entre os Wauja (Piedade, 2004; Mello, 2005), Kamayurá (Menezes Bastos, 1990, 1999) e Javaé, a casa dos homens é frágil porque é feita de palha, ao passo que seu significado simbólico constitui-se como sendo a principal barreira de proibição e ocultação de seu interior aos olhos das mulheres.

A vigilância é uma constante entre os homens durante o ritual, tanto que entre os Mehinaku (Gregor; Tuzin, 2001, p. 618) e Wauja (Mello, 2005), as mulheres devem ficar dentro de suas casas, de portas fechadas, ao passo que os homens tocam as flautas na praça. De modo similar, entre os Javaé, as mulheres devem ficar dentro de suas casas quando os Aruanãs e Worosỹ chegam à aldeia ou quando vão embora, qualquer deslocamento deles para o lugar mítico ou uma pequena viagem com os homens nas pescarias rituais, deve ser evitado dos olhares das mulheres e crianças, assim como a fabricação das máscaras, a identidade dos dançarinos e cantores não deve ser revelada. Elas são proibidas de entrar na casa de Aruanã, a menos que seja uma mulher velha que já não menstrua mais, como é o caso das Hawyky wetxu, mulheres que ocupam a posição de 'subordinadas' dos Worosỹ. Ehrenreich (1948, p. 76-77) nota que entre os Karajá, as mulheres constituem a platéia das cerimônias, mas "os homens não lhes permitem ver as máscaras sem os seus portadores, pois são mantidas na crença de estarem vendo realmente os respectivos espíritos de animais". Exceções fazem-se apenas com as mulheres mais idosas, às quais se revela às vezes o segredo". Observa-se ainda que se porventura uma mulher entrar na casa de Aruanã e olhar as máscaras sem os seus portadores, sofre a sanção ou da morte ou do estupro coletivo. Lima Filho (1994, p. 85-86) aponta a tentativa dos homens em ocultar a identidade do cantor e dançarino, dizendo que "seria uma quebra de sigilo de conseqüências graves, como a morte das mulheres que teriam tido acesso aos segredos dos homens". No término de cada cerimônia, as máscaras são queimadas, aproveitando-se apenas as penas de araras que hoje são muito raras na Ilha do $\mathrm{Ba}-$ nanal. A cada novo ciclo de brincadeiras de Aruanãs, o xamã e um grupo de homens se dedicam na confecção de novas máscaras, pois dominam a habilidade artística de moldá-las como 'cópias' do mundo subaquático.

Os rituais e seus segredos têm como caracterís- tica, nas duas regiões, a agressão contra as mulheres na forma de estupro coletivo se elas romperem com o tabu ao olhar e tocar os objetos sagrados. Os mitos e o mundo que eles descrevem projetam uma visão das mulheres associadas como seres perigosos e poderosos. Há uma 'ambivalência moral' que agita as idéias de inflexão de gênero, uma vez que as excluem dos ritos e, ao mesmo tempo, imitam seus poderes gerativos na iniciação dos jovens (Gregor; Tuzin, 2001, p. 322). Mello (2005, p. 137) mostra que no caso do ritual iamurikuma das mulheres Wauja, prevalece mais a posição simbólica da ambigüidade sexual e menos a posição de assumir a identidade masculina. Ao se aproximarem da masculinidade, as mulheres Wauja "assumem uma posição simbolicamente perigosa: aquela de uma ambigüidade sexual [...]. O ambíguo de não ser mais mulher nem homem, o encontro do masculino e do feminino em um único ser".

Se a paisagem teórica e etnográfica sobre a Amazônia mudou nos últimos 30 anos, a preocupação era em desnaturalizar a figura do índio ou como 'bom selvagem' ou como 'bárbaro e primitivo' do imaginário social da sociedade envolvente, agora o objetivo é desnaturalizar a questão de gênero da noção dualista que caracterizou os estudos etnológicos do projeto Harvard Central Brazil (HCB) sobre as sociedades JêBororo (Maybury-Lewis, 1979) e pensar a construção do feminino e do masculino com base na perspectiva relacional entre alteridade e identidade (Lasmar, 1999, p. 147). O modelo dualista define essas sociedades organizadas em torno de aldeias circulares, com casas situadas em volta de uma praça central, o espaço da casa dos homens interditada às mulheres, e palco da vida cerimonial. Nessa ótica, as relações entre homens e mulheres estariam replicando o princípio dualista em que o mundo dos homens seria a superestrutura, e o mundo das mulheres a infra-estrutura. Da mesma forma, a uxorilocalidade refletiria a casa dos homens onde os mais novos estariam subordinados aos mais velhos, como se a mulher não tivesse papel político sobre a unidade residencial. Entre os Mebengôkre (Lea, 1999) o modelo dualista não é tão fechado assim, pois as matri-casas como 'pessoas morais', são detentoras de bens simbólicos como os nomes pessoais de ambos os sexos e os enfeites e papéis cerimoniais. Em cada 'casa', as prerrogativas são bilaterais, os amigos formais são herdados por ambos os sexos que irão acompanhar nos ritos de iniciação masculina, homens e mulheres classificam os filhos de seus irmãos na mesma categoria que seus netos, as tarefas masculinas se estendendo à fabricação do artesanato (cestos e cocares).

Nos povos de língua Aruak, as relações de gênero estão fundadas muito mais na ambigüidade e na complementaridade das relações de gênero que numa oposição dualista, mesmo diante da existência de relações de oposição entre feminino e masculino, especialmente na vida cerimonial (Chernela, 1988, p. 45; 
Lasmar, 2005, p. 103). Entre os Kulina da região do Alto Purús no Acre (Bueno da Silva, 1997, p. 71) os homens são associados à natureza, à floresta, ao perigo e ao descontrole, ao passo que as mulheres são associadas à cultura, ao doméstico e à aldeia. Para os Wauja (Mello, 2005) o ritual musical iamurikuma feminino é uma contrapartida das flautas kawoká, ritual exclusivamente masculino interditado às mulheres. No ritual, há uma série de cantos, chamados kawokakumã, que apresentam muitas semelhanças musicológicas com as peças das flautas kawoká (Piedade, 2004).

\section{Conclusão}

Para Blacking (1995, p. 33-59), a música "é som organizado dentro de padrões socialmente elaborados", ou seja, cada sistema cultural tem seu próprio ritmo, no sentido consciente da experiência situada em ciclos de mudança de estações, economia, profundidade ou extensão genealógica, ciclo de vida e sucessão política. As emoções específicas que a música desencadeia em determinados eventos da vida social não podem ser analisadas fora das experiências sociais, uma vez que a música não é um escape da realidade, mas uma aventura no interior da realidade, a realidade virtual dos mundos cosmológicos.

Para Rodrigues (2008, p. 805, grifo da autora), a dança dos aruanãs é "um ritual antialiança (...) mais interessada na recriação cerimonial da imortalidade do que na afirmação do valor da vida em sociedade". Ou seja, as brincadeiras de Aruanãs, como ritos performativos, parecem apontar para a experiência de mimetizar um outro mundo, o mundo dos seres mágicos.

O mundo subaquático (Berahatxi) e o mundo celeste (Biuwètyky) são os espaços nos quais os Aruanãs cantam e dançam, pela eficácia do poder de criação da palavra (xiburè), estes seres vivem eternamente num mundo sem morte, doenças ou perda de substâncias. E a música é o elemento essencial deste estado de alegria. De um lado, os homens, quando cantam e dançam, não estão apenas reproduzindo as prerrogativas cerimoniais da vida entre os afins, mas mimetizando o desejo de alcançar este estado de imortalidade. De outro, as canções dos Aruanãs tematizam o desejo sexual, o sexo, as mulheres como seres insatisfeitos sexualmente. Como já disse, não cantam somente isso. Assim, os Aruanãs cantam aquilo que é proibido aos seres sociais, residindo aí, talvez, a razão da ocultação dos nomes e da identidade da pessoa sobre quem se canta e para quem se canta. Tudo indica que a música, na cena ritual, opera, ora como o signo de um estado de 'alegria' de um mundo desejado ora como uma forma teconímia da socialidade Javaé.

\section{Referências}

AYTAI, Desidério. O sistema tonal da música Karajá. In: Revista do Museu Paulista, v. 26, p. 257- 265, 1979.

BAKHTIN, Mikhail. Os gêneros do discurso. In: Estética da criação verbal. São Paulo: Martins Fontes, 2000.

BARCELOS NETTO, Aristóteles. $A$ arte dos sonhos: uma iconografia ameríndia. Lisboa: Museu Nacional de Etnologia, 2002.

BLACKING, J. Music, culture and experience: selected papers of J. Blacking. Chicago: University of Chicago Press, 1995.

BRÍGIDO, Suely. A imagem do princípio. A música e o ritual da dança do Aruanã. Índios Karajá - Brasil Central. In: OVERATH, Johannes (ed.). Musices Aptatio. Die musikkulturen der indianer Brasiliens I. Roma, Itália, p. 271-391, 1994/1995.

BUENO DA SILVA, Domingos A. Música e pessoalidade: por uma antropologia da música entre os Kulina do Alto Purus. Dissertação (Mestrado em Antropologia Social). Programa de Pós-Graduação em Antropologia Social. Universidade Federal de Santa Catarina, Florianópolis, 1997. CARNEIRO DA CUNHA, Manuela. Les études Gê. L'Homme. 126-128. XXXIII, 1993.

CHERNELA, Janet M. "Righting History in the North- west Amazon: myth, structure, and history in an Arapaço Narrative" In: HILL, Jonathan D. (Org.). Rethinking History and myth. Indigenous south american perspectives on the past. Urbana and Chicago. University of Illinois Press, 1988, p.35-49.

CONRAD, Rudolf. WERU WIU - Musik der maske weru beim Aruanãs-Fest der Karajá-Indianer, Brasilien. Société Suisse dês Américanistes. Bulletin 61, p. 45-62, 1997. EHRENREICH, Paul. As Tribos Karajá do rio Araguaia (Goiaz). In: Revista do Museu paulista. Nova Série. São Paulo, v. II, p. 20-136, 1948.

GREGOR, Thomas A; TUZIN, Donald. The anguish of gender: men's cults and moral contradiction in Amazonia and Melanesia. In: Gender in Amazonia and Melanesia: an exploration of the comparative method. Berkeley and Los Angeles: University of California Press, p. 309-336, 2001.

LASMAR, Cristiane. Mulheres indígenas: representações. In: FRANCHETTO, Bruna. (Org.). Dossiê mulheres indígenas. Estudos Feministas, v. 7, n. 1 e 2. CFCH/UFSC; IFCS/UFRJ, p.143-156, 1999.

De Volta ao Lago de Leite. Gênero e transformação no Alto Rio Negro. São Paulo: Ed. Unesp/ISA/NUTI, 2005 . 
LEA, Vanessa R. Desnaturalizando gênero na sociedade Mebengôkre. In: FRANCHETTO, Bruna (Org.). Dossiê mulheres indígenas. Estudos Feministas, v. 7, n. 1 e 2. CFCH/UFSC; IFCS/UFRJ, p. 176-194, 1999.

LIMA FILHO, Manuel F. Hetohokỹ. Um rito Karajá. Goiânia: Editora da UCG, 1994.

MAIA, Marcus A. R. Aspectos tipológicos da língua Javaé. Dissertação (Mestrado em Letras, Lingüística) - Faculdade de Letras da UFRJ, Rio de Janeiro, 1986.

MAYBURY-LEWIS, David. Dialectical societies: the Gê and Bororo of Central Brazil. Cambridge, Massachusetts: Harvard University Press, 1979.

MELLO, Maria Ignês C. Iamurikuma: música, mito e ritual entre os Wauja do Alto Xingu. Tese (Doutorado em Antropologia Social) - Programa de Pós-Graduação em Antropologia Social da Universidade Federal de Santa Catarina, Florianópolis, 2005.

MENEZES BASTOS, Rafael. A Festa da jaguatirica: uma partitura crítico-interpretativa. Tese (Doutorado em Antropologia Social) - Programa de Pós-Graduação em Antropologia Social. Universidade de São Paulo, São Paulo, 1990.

A Musicológica Kamayurá. Para uma antropologia da comunicação no Alto Xingu. Florianópolis: Ed. UFSC, [1976]1999.

Leonardo, a flauta: uns sentimentos selvagens. Revista de Antropologia, São Paulo, USP, v. 49, n. 2, p. 558-579, 2006.

A música nas sociedades indígenas das Terras Baixas da América do Sul. Mana, 13, v. 2, p. 293-316, 2007.

MONTARDO, Deise Lucy Oliveira. Através do Mbaraka: música e xamanismo Guarani. Tese (Doutorado em Antropologia Social) - Programa de Pós-Graduação em Antropologia Social. Universidade de São Paulo, 2002.

PÉTESCH, Nathalie. La pirogue de sable: Pérennité cosmique et mutation sociale chez les Karajá du Brésil central. Langues et societés d'Amérique traditionnelle, 8. Paris. Éditions Peeters, 2000.
PIEDADE, Acácio Tadeu de C. O canto do Kawoká: música, cosmologia e filosofia entre os Wauja do Alto Xingu. Tese (Doutorado em Antropologia Social) - Programa de Pós-Graduação em Antropologia Social. Universidade Federal de Santa Catarina, Florianópolis, 2004.

RODRIGUES, Patrícia de Mendonça. O Povo do Meio. Tempo, cosmo e gênero entre os Javaé da Ilha do Bananal. Dissertação (Mestrado em Antropologia Social) - Universidade de Brasília, Brasília, 1993.

Tanyxiwè's journey a Javaé theory of history. Tese (Doutorado). The University of Chicago, Chicago, Illinois, 2008, v. 1, 2, 3.

SEEGER, Anthony. Os índios e nós. Estudos sobre sociedades tribais brasileiras. Rio de Janeiro: Campus, 1980.

Why Suyá Sing. A musical anthropology of an Amazonian people. Urbana and Chicago: University of Illinois Press, [1987] 2004.

STRATHERN, Marilyn. The gender of the gift. Problems with women and problems with society in Melanesia. Berkeley and Los Angeles: University of Califórnia Press, 1988.

TAMBIAH, S. J. Culture, thought, and social action. An anthropological perspective. Cambridge, Mass.: Harvard University Press, p. 123-166, 1985.

TORAL, André. Cosmologia e sociedade Karajá. Dissertação (Mestrado em Antropologia Social) - Programa de PósGraduação em Antropologia Social. Museu Nacional. Universidade Federal do Rio de Janeiro, Rio de Janeiro, 1992.

VÉRAS, Karin Maria. A dança Matipu: corpos, movimentos e comportamento no ritual xinguano. Dissertação (Mestrado em Antropologia Social) - Programa de PósGraduação em Antropologia Social. Universidade Federal de Santa Catarina, Florianópolis, 2000.

VIVEIROS DE CASTRO, Eduardo B. Araweté. Os deuses canibais. Rio de Janeiro: Jorge Zahar/ANPOCS, 1986.

Os pronomes cosmológicos e o perspectivismo ameríndio. Mana, v. 2, n. 2, p. 115-143, 1996.

\section{The Dance of the Aruanãs: Myth, Ritual and Music amongst the Javaé.}

\section{Abstract}

This paper proposes an analysis of the ritual-musical child plays (tykydisy) among the Javaé, ancient inhabitants of the Araguaia valley, especially those from the Bananal Island, state of Tocantins, Brazil. Aruanãs are magical beings of the underwater world (Berahaxti) brought about by the shaman to play (sing and dance) with social beings in the outside world (Ahana Òbira) during a ceremonial cycle. Firstly, I focus on the Aruanãs' ceremonial cycle as the maximum expression of matrimonial bounds (tykówy) between fathers-in-law and sons-in-law; secondly, I analyze Aruanãs pairs as androgynous body forms. The Aruanãs are conceived as magical bodies from a world in which they have no difference in gender. Aruanãs' plays are performance rituals in which music and dance promote the updating of the myth-cosmology and the wealth circulation among the Javaé.

Key words: body; gender; Javaé; music; ritual.

Data de recebimento do artigo: 07-06-2008

Data de aprovação do artigo: 28-08-2008 